\title{
Constraints in the Application of Partnerships in Islamic Banks: The Present Contributions and Future Directions
}

\begin{abstract}
Muhammad Nouman ${ }^{1}$, Karim Ullah ${ }^{2}$
Abstract

Partnership is considered as the essence of Islamic banking. Therefore, Islamic banks are supposed to rely on the partnership contracts for acceptance of deposits and investment of funds. In practice, Islamic banks adopt partnership contracts for accepting deposits. However, these are rarely used while investing. All over the world, Islamic banks rely heavily on non-partnership contracts for investment of funds. The present paper provides a critical review of the extant literature on the rare use of partnership contracts by Islamic banks for investment purposes. This review highlights the contributions that extant literature has made to the current knowledge about the constraints in the application of partnership contracts in Islamic banks. From this review, concentrations of research efforts are identified and directions for future research are proposed.
\end{abstract}

Keywords: constraints, partnership, contracts, Islamic bank.

\section{Introduction}

The contracts of Islamic finance are based on two principles: Partnership and non-partnership (ElGindi, Said, \& Salevurakis, 2009; Sundararajan \& Errico, 2002). Partnership, commonly known as the profit and loss sharing (PLS) paradigm, allows a financial institution to earn profit on invested capital if the financial institution is willing to tolerate loss in case of the project failure (Aggarwal \& Yousef, 2000; Bacha, 1997). The allocation of reward and risk to each partner, and the distribution of responsibilities among them are defined in the contract which is enforced by the social values and the ethical standards set in the Shariah (Hearn, Piesse, \& Strange, 2012).

Contracts based on the partnership principle include Musharakah and Mudarabah. A Musharakah contract is a type of partnership where all partners jointly contribute capital and manage the business venture (Abdouli, 1991; ElGindi et al., 2009). Profits are shared based on a pre-negotiated ratio, while losses are borne in proportion to the capital contributed by the partners (Aggarwal \& Yousef, 2000; Hearn et al.,

1 Ph.D. Scholar at the Institute of Management Sciences, Peshawar, Pakistan and Lecturer at the Institute of Business and Management Sciences (IBMS), The University of Agriculture, Peshawar, Pakistan. mnouman@aup.edu.pk

2 Assistant Professor and Coordinator of Centre for Excellence in Islamic Finance (CEIF) at the Institute of Management Sciences, Peshawar, Pakistan, karim.ullah@imsciences.edu.pk 
2012; Kayed, 2012; Yousefi, McCormick, \& Abizadeh, 1995). On the other hand a Mudarabah contract is a type of partnership between investor(s) (Rabb al-mal) and entrepreneur(s) (Mudarib),where the investor contributes capital while the entrepreneur employs labour and manages the venture (Abdouli, 1991; Aggarwal \& Yousef, 2000). Profits are divided according to a pre-determined ratio, while the losses are exclusively borne by the investor.

The non-partnership contracts do not involve profit and loss sharing and entrepreneur usually has to pay a predetermined return. The non-partnership modes include Ijara (lease), Murabahah ('mark-up' or cost plus sale), Bai Muajjal (deferred payment), Istisna' (commission to manufacture), Salam (deferred delivery), Qard Al Hasana (charity loan) and Jo'alah (service fee) (El-Komi \& Croson, 2013; Khan, 2010).

Advocates of Islamic banking concede that the partnership contracts are the ideal modes of financing and represent the true spirit of Islamic banking (Ahmad, 2000; Dusuki, 2007; Siddiqi, 1985). Therefore, partnership contracts should dominate the operations of Islamic banks. On the other hand, the non-partnership contracts should only be used where partnership contracts are not applicable (Khan, 2010; Usmani, 2007).

The present paper critically reviews the extant literature on the use of partnership contracts by Islamic banking institutions for investment purposes. The underlying objective of this review is to identify and synthesize constraints faced by Islamic banks in the application of partnership contracts for investment purposes. This discussion is developed further by providing certain suggestions for Islamic banking researchers regarding what could be researched further in order to develop a policy framework for these institutions to adopt partnership-based investment models more widely. Therefore, the present critique of literature is important for the consolidation of knowledge and development of research in this area.

Rest of the paper proceeds as follows: Section 2 and 3 shed light on the idealization of partnership contracts in Islamic banking and finance literature and its marginalization in the practices of Islamic banks respectively. Section 4 presents a review of the extant literature outlining the constraints in the application of partnership contracts. Section 5 presents a commentary on the opportunities that future researches can fruitfully pursue, Section 6 concludes the paper.

\section{Partnership in Islamic Banking Literature}

Partnership provides foundation for Islamic banking (Algaoud \& Lewis, 2007; Ariff, 1988; Lewis, 2008; Zaher \& Hassan, 2001). According to Gafoor (1995), the earliest references to the reorganization of banking system on the basis of partnership instead 
of interest can be found in the pioneering work by Anwar Iqab Qureshi, Mahmud Ahmad, and Naiem Siddiqi in late forties, followed by Abul A'ala Mawdudi in 1950.

Two pioneer Islamic economists including Anwar Iqbal Qureshi and Mahmud Ahmad proposed a banking system based on partnership (Shinsuke, 2012). Anwar Iqbal Qureshi in his book "Islam and the Theory of Interest" stated that interest is prohibited in Islam but partnership is not. In Islamic system there is no objection against a bank if it becomes partner with business ventures and shares profit and losses instead of giving them loans (Qureshi, 1946, pp. 158-159). His statement implies that the partnership-based financial contracts, i.e., musharakah and mudarabah, are more appropriate for the Islamic financial system (Shinsuke, 2012). Mahmud Ahmad, around the same time, mentioned his preference for partnership-based systems in his book. He stated that "the Shirakat banks would lend money to industry and commerce on the basis of Shirakat, that is, they would share the profit with their debtors rather than burden industry and commerce with a fixed rate of interest" (Ahmad, 1947, p. 170).

Siddiqi (1981) called the works of Anwar Iqbal Qureshi and Mahmud Ahmad pioneering in the literature of Islamic economics because most Islamic economists of the next generation followed their lead and encouraged partnership-based contracts as preferable instruments for Islamic finance (Shinsuke, 2012).

Muhammad Uzair and Muhammad Nejatullah Siddiqi, among the next generation scholars, made important contributions in developing a theory to make the proposed Islamic banking feasible in practice. In 1951, Uzair proposed the practical idea of mudarabah, which was later known as "two-tier mudarabah" (Uzair, 1978). According to Shinsuke (2012) the idea of Uzair was to use two mudarabah transactions in one scheme where depositors ( $\mathrm{rabb}$ al-mal) would invest money with the bank ( $m u$ darib) on mudarabah basis, while bank (rabb al-mal) too would invest this money with the borrower (mudarib) on mudarabah basis. Thus the depositors (rabb al-mal) and the bank (mudarib) would conduct the first mudarabah, while the bank (rabb al-mal) and the borrower (mudarib) would conduct the second mudarabah (see Figure 1). Parties of the first mudarabah would share the bank's profit while those of the second mudarabah would share the borrower's profit.

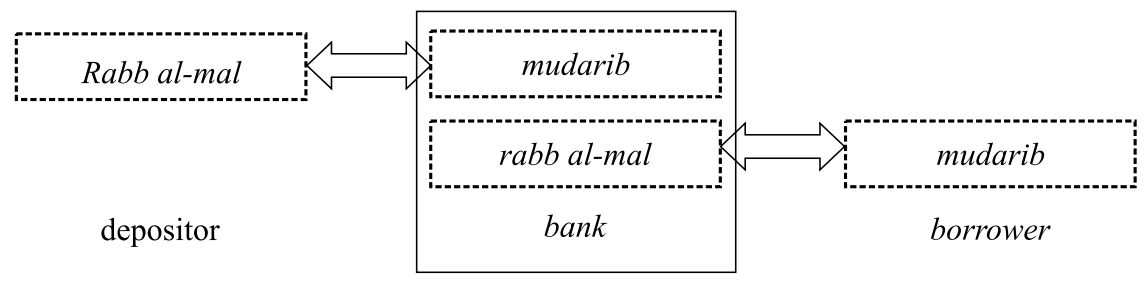

Source Shinsuke (2012)

Figure 1: Mechanism of two-tier mudarabah 
In 1969, Siddiqi contributed by developing a comprehensive picture of a mudarabah-based Islamic financial system. He not only elaborated the theory of two-tier mudarabah, but also expanded its application to the relationship between central bank and commercial banks (Siddiqi, 1983a).

Thus, it is evident that partnership has provided foundation for the Islamic banking system. The advocates of Islamic banking therefore claim that Islamic banks are supposed to act as suppliers of venture capital, financing promising ideas, and worthy ventures in exchange for share in the profits (Khan, 2010). Moreover, it is generally believed that the basic philosophy of Islamic banking cannot be translated into reality unless Islamic banks expand the use of partnership contracts (See for example, Sadique, 2012; Siddiqi, 1983b; Usmani, 2002, 2007).

The advocates of Islamic banking claim that partnership contracts are preferable to non-partnership contracts for several reasons: including their risk sharing features (Dar \& Presley, 2000; Ebrahim \& Safadi, 1995; Farooq, 2007). Partnership can play a vital role in gearing up economic stability and growth in several ways. First, promoting partnership in Islamic financial institutions (IFIs) will reduce the financial constraints faced by small and medium enterprises (SMEs) and new firms. Small and new firms hardly have any access to finances from traditional financial institutions because these firms often do not have enough acceptable physical collateral or track record to obtain finances from institutional sources (Berger \& Udell, 1998). Partnership contracts of Islamic finance best suit the needs of such businesses as they provide Islamic bank an opportunity to share in the success of any enterprise without penalizing businesses unduly for any failure (Wilson, 2002). Therefore, promoting partnership in IFIs will elevate economic growth by supporting SMEs.

Second, partnership makes financiers participate in the risks of venture which induce them to assess the risks with utmost care and monitor the borrowers. The twofold assessment of investment proposals by both the borrower and the lender would help introduce greater health and stability into the financial sector (Chapra, 2002).

Third, according to ElGindi et al. (2009) only those projects are financed in the conventional system which are capable of repaying the principal amounts and interest. Therefore, other projects, in spite of their potential long-term profitability, might be ruled out. On the other hand in partnership based financing, projects are allocated solely on the basis of their potential productivity and profitability instead of their creditworthiness. Therefore, adopting a partnership system could increase the volume of investments, and thus increase worthwhile employment opportunities.

Fourth, according to Hicks (1982) interest has to be paid in both good and bad 
times alike; whereas dividends can be reduced in bad times and can even be skipped in extreme situations. This factor should significantly reduce business failures, and in turn reduce, instead of promoting, economic instability.

Finally, partnership contracts ensure availability of more financial resources to small businesses and promote justice and equity in society since all deserving ventures get financed and not just the ventures with well-established credit history or excellent collateral (Khan, 2010). Therefore, most advocates of Islamic Banking hold that a financial system based on risk sharing would lead to greater allocative efficiency, equity, GDP growth, and financial system stability (Iqbal \& Molyneux, 2005).

\section{Partnerships in the Current Practices of Islamic Banks}

Islamic banks adopt partnership contracts for the scheme of deposits, especially for term deposit accounts. However, contrary to the expectations of advocates of Islamic banking, Islamic banks do not adopt partnership contracts as the main investment scheme. Many scholars have pointed out this issue at various forums (See for example:Abou-Gabal, Khwaja, \& Klinger, 2011; Aggarwal \& Yousef, 2000; Ahmed, 2002; Amrani, 2012; Ariff, 1988; Bacha, 1995, 1997; Chong \& Liu, 2009; Dar \& Presley, 2000; Dusuki, 2007; El-Gamal, 2005; Farooq, 2007; Hanif \& Iqbal, 2010; Hasan, 2002; Iqbal \& Molyneux, 2005; Kayed, 2012; Khan, 2010; Lewis, 2008; Mirakhor \& Zaidi, 2007; Sadique, 2010, 2012; Samad, Gardner, \& Cook, 2005; Shinsuke, 2012; Siddiqi, 1983b, 1985, 2006; Usmani, 2007; Vahed \& Vawda, 2008; Vogel \& Hayes, 1998; Yousef, 2004; Zaher \& Hassan, 2001). By far, the non-partnership contracts, especially Murabahah and Ijara, are the most dominant method for investing the funds.

Given the dominant reliance on non-partnership contracts, Islamic banking cannot be referred to as risk-sharing in any meaningful sense (Khan, 2010). The non-partnership contracts might be deemed satisfactory in fulfilling the requirements of Shariah compliance, but these are clearly insufficient to achieve the specific objectives of Islamic banking and the broader goals of Shariah (Kayed, 2012; Sadique, 2012; Siddiqi, 2006).

\section{Constraints in the Application of Partnership Contracts}

The strong and consistent tendency of Islamic financial institutions to rely on non-partnership contracts while lending results from necessity, not from preference (Bacha, 1995; Karim, 2002). Musharakah and Mudarabah have serious practical problems (Sumarti, Fitriyani, \& Damayanti, 2014). To avoid the problems in partnership contracts Islamic banks rely mainly on non-partnership contracts while investing funds. Therefore, to promote partnership it is necessary to first identify the underlying 
problems of partnership contracts and the constraints faced by Islamic banks in the application of these contracts.

Many authors have provided different explanations for the under-utilization of the partnership contracts. However, literature remains scattered with diverse studies focused on different dimensions of the issue. Therefore to produce a coherent view, major constraints outlined in the extant literature have been consolidated. Table 1 summarizes factors hindering the application of Musharakah and Mudarabah modes of financing in the view of different researchers.

Table 1. Constraints in the application of partnership contracts

\begin{tabular}{|c|c|}
\hline CONTRIBUTORS & CONSTRAINTS \\
\hline $\begin{array}{l}\text { Ascarya (2010); Ascarya and Yumanita (2006); Sadique } \\
\text { (2012) }\end{array}$ & $\begin{array}{c}\text { Upper management of Islamic banks is } \\
\text { not committed and sincere in devising } \\
\text { workable alternatives based on partner- } \\
\text { ship. }\end{array}$ \\
\hline $\begin{array}{l}\text { Akacem and Gilliam (2002); Khan (1995); Sadique (2010, } \\
\text { 2012); Samad et al. (2005) }\end{array}$ & Lack of skilful human resource. \\
\hline $\begin{array}{l}\text { Abou-Gabal et al. (2011); Boumediene (2011); Hasan } \\
\text { (2002); Vahed and Vawda (2008) }\end{array}$ & Higher risk \\
\hline $\begin{array}{l}\text { Dar, Harvey, and Presley (1999); Dar and Presley (2000); } \\
\text { Farooq (2007); Samad et al. (2005) }\end{array}$ & Lack of applicability \\
\hline Khan (1995); Sadique (2012) & $\begin{array}{c}\text { More complicated to structure and deal } \\
\text { with partnership contracts. }\end{array}$ \\
\hline Samad et al. (2005); Usmani (2002) & $\begin{array}{l}\text { Partnership contracts may disclose the } \\
\text { secrets of the business to the financier } \\
\text { and other parties }\end{array}$ \\
\hline Hanif and Iqbal (2010); Khan (1989); Siddiqi (1991) & $\begin{array}{l}\text { Low levels of reliability and trustworthi- } \\
\text { ness in the market }\end{array}$ \\
\hline Dar et al. (1999); Dar and Presley (2000); Khan (2010) & $\begin{array}{l}\text { Lack of properly defined or protected } \\
\text { property rights in Muslim countries }\end{array}$ \\
\hline $\begin{array}{l}\text { I.C.M.T Force (2004); Khan (1995); Naughton and } \\
\text { Naughton (2000); Solé (2007); Zaher and Hassan (2001) }\end{array}$ & $\begin{array}{c}\text { Absence of a supportive regulatory and } \\
\text { legal framework }\end{array}$ \\
\hline $\begin{array}{l}\text { Abou-Gabal et al. (2011); Archer, Karim, and Al-Deehani } \\
\text { (1998) }\end{array}$ & $\begin{array}{c}\text { Low quality and quantity of accounting } \\
\text { information }\end{array}$ \\
\hline $\begin{array}{l}\text { Iqbal (1997); Khan (1995); Naughton and Naughton } \\
\text { (2000); Zaher and Hassan (2001) }\end{array}$ & $\begin{array}{l}\text { Illiquid and shallow secondary market } \\
\text { for Islamic financial instruments }\end{array}$ \\
\hline Dar and Presley (2000) Dar et al. (1999); Sadique (2010) & $\begin{array}{l}\text { Unfair treatment in taxation and Tax } \\
\text { evasion }\end{array}$ \\
\hline $\begin{array}{l}\text { Chong and Liu (2009); Dar et al. (1999); Dar and Presley } \\
\text { (2000); Hanif and Iqbal (2010); Khan (1995); Pryor } \\
\text { (2007); Samad et al. (2005) }\end{array}$ & $\begin{array}{l}\text { Severe competition from conventional } \\
\text { banks and other financial institutions. }\end{array}$ \\
\hline Ascarya (2010); Ascarya and Yumanita (2006) & $\begin{array}{c}\text { Lack of commitment and support from } \\
\text { government }\end{array}$ \\
\hline
\end{tabular}




\begin{tabular}{|c|c|}
\hline $\begin{array}{l}\text { Naughton and Naughton (2000); Siddiqi (1991); Solé } \\
\text { (2007); Zaher and Hassan (2001) }\end{array}$ & $\begin{array}{c}\text { Lack of sound accounting procedures } \\
\text { and standards consistent with the } \\
\text { Islamic laws }\end{array}$ \\
\hline $\begin{array}{l}\text { Ascarya (2010); Ascarya and Yumanita (2006); I.C.M.T } \\
\text { Force (2004) }\end{array}$ & $\begin{array}{l}\text { Lack of understanding and knowledge } \\
\text { among society regarding the fundamen- } \\
\text { tals of the Islamic finance and banking }\end{array}$ \\
\hline Hanif and Iqbal (2010); Khan (1989); Siddiqi (1991) & $\begin{array}{l}\text { Low levels of reliability and trustworthi- } \\
\text { ness in the market }\end{array}$ \\
\hline Ascarya (2010);Ascarya and Yumanita (2006) & Low demand for PLS financing \\
\hline $\begin{array}{l}\text { Adnan and Muhamad (2008); Aggarwal and Yousef } \\
\text { (2000); Akacem and Gilliam (2002); Al-Suwailem (1998); } \\
\text { Amrani (2012); Archer et al. (1998); Ascarya (2010); As- } \\
\text { carya and Yumanita (2006); Bacha (1997); Bashir (1996); } \\
\text { Chong and Liu (2009); Dar et al. (1999); Dar and Presley } \\
\text { (2000); Farooq (2007); Hasan (2002); Kayed (2012); } \\
\text { Khan (1995); Khan and Ahmed (2001); Mirakhor and } \\
\text { Zaidi (2007); Sadique (2012); Samad et al. (2005); Sarker } \\
\text { (1999); Siddiqi (1983b, 2006); Sundararajan and Errico } \\
(2002)\end{array}$ & Agency problem \\
\hline $\begin{array}{l}\text { Adnan and Muhamad (2008); Aggarwal and Yousef } \\
\text { (2000); Ahmed (2002); Al-Suwailem (1998); } \\
\text { Archer et al. (1998); Ascarya (2010); Ascarya and Yumani- } \\
\text { ta (2006); Bashir (1996); El-Din (2008); Farooq (2007); } \\
\text { Hasan (2002); Khan (2010); Khan (1995); Khan (1989); } \\
\text { Sadique (2010); Sarker (1999); Sundararajan and Errico } \\
\text { (2002) }\end{array}$ & Asymmetric information \\
\hline $\begin{array}{l}\text { Aggarwal and Yousef (2000); Al-Suwailem (1998); Archer } \\
\text { et al. (1998); Ascarya (2010); Ascarya and Yumanita } \\
\text { (2006); Bashir (1996); El-Gamal (2005); Khan (2010); } \\
\text { Khan (1995); Khan and Ahmed (2001); Pryor (2007); } \\
\text { Sarker (1999); Siddiqi (1983b, 2006) } \\
\end{array}$ & Adverse selection \\
\hline $\begin{array}{l}\text { Abou-Gabal et al. (2011); Adnan and Muhamad (2008); } \\
\text { Aggarwal and Yousef (2000); Ahmed (2002); Amrani } \\
\text { (2012); Ascarya (2010); Ascarya and Yumanita (2006); } \\
\text { Bacha (1997); Bashir (1996); Chong and Liu (2009); Dar } \\
\text { et al. (1999); Dar and Presley (2000); Dees (1992); El-Din } \\
\text { (2008); El-Gamal (2005); Farooq (2007); Khan (2010); } \\
\text { Khan (1995); Khan and Ahmed (2001); Khan (1989); } \\
\text { Kuran (1995); Pryor (2007); Rethel (2011); Sarker (1999); } \\
\text { Sen (1987); Siddiqi (1983b); Solé (2007); Sundararajan } \\
\text { and Errico (2002); Usmani (2002); Wolozin (2002); Zaher } \\
\text { and Hassan (2001) }\end{array}$ & Moral hazards \\
\hline $\begin{array}{l}\text { Akacem and Gilliam (2002); Chong and Liu (2009); } \\
\text { Khan (1989); Mirakhor and Zaidi (2007) }\end{array}$ & Higher monitoring costs \\
\hline Ascarya (2010); Ascarya and Yumanita (2006) & Risk averse depositors \\
\hline
\end{tabular}


The extant literature indicates that the asymmetric information, adverse selection, moral hazards and agency problems in partnership contract are the dominant constraints. Asymmetric information is a situation that arises when insufficient knowledge of one party about the other one involved in a transaction makes it impossible to take accurate decisions while conducting that transaction (Mishkin \& Eakins, 2011). Since partnership contracts are formulated in the form of principal-agent arrangements (Bashir, 1996), these are prone to the asymmetric information problem. The agent (an entrepreneur who seeks funds) being an insider party has better knowledge about the project he/she wishes to undertake; whereas the principal (a bank which provides the funding needed to initiate the project) being an outsider party usually has less knowledge about potential returns and the associated risks of the project than the agent does (Khalil, Rickwood, \& Murinde, 2002). This asymmetric information creates problems in the partnership arrangements on two fronts, i.e. before the project is initiated (adverse selection), and after it has started (moral hazards).

Adverse selection is the problem of lending money to inappropriate applicants. It is faced due to asymmetric information before occurrence of the transaction (Mishkin \& Eakins, 2011). Borrowers have better inside information about themselves (including their abilities and intentions) and project (including its potential returns and likelihood of success), but they may not credibly signal it to the bank in the wake of exploiting interest of bank for their own benefits (Iqbal \& Molyneux, 2005; Sarker, 1999). Since it is difficult for banks to determine the quality of a loan applicant, this creates adverse selection problems (Mills \& Presley, 1999) because it is more likely that funds might be lent to inappropriate applicants. To control the adverse selection problem bank has to appraise the projects with utmost care.

On the other hand, moral hazard (ex-post asymmetric information) is the problem faced due to asymmetric information after a project is initiated (Mishkin \& Eakins, 2011). Moral hazard in partnership arrangements is the risk (hazard) that borrower might involve in activities that are undesirable (immoral) from the bank's point of view. These problems are associated with under reporting or artificial reduction of the actual profit and the difficulty of observing the entrepreneur's actions (Amrani, 2012). The Islamic bank would therefore need to incur costly monitoring expenses to ensure that the behaviour of entrepreneur is consistent with the bank's interests.

The adverse selection and moral hazard problems induce high risk of default in partnership arrangement. Moreover, the additional dead weight costs in pre-contract project appraisal and post-contract monitoring to control these risks make partnership agreements more costly (Sarker, 1999). Therefore the inherent high risk and additional costs make partnership contracts less attractive for Islamic banks. 


\section{The Present Contributions and Future Directions}

The extant literature outlines different reasons for marginalization of partnership contracts by Islamic banks. However, an important limitation of this literature is its overwhelming focus on the academia's view point, i.e., it presents the view point of academia regarding constraints in the application of partnership contracts (See for example Bacha, 1995, 1997; Bashir, 1996; Dar \& Presley, 2000; Farooq, 2007; Kayed, 2012; Khan, 2010; Samad et al., 2005) but the practitioners' view point remains relatively ignored. There is a lack of researches which could provide the viewpoint of practitioners on the problem of rare utilization of partnership contracts. Although a limited number of studies in the extant literature investigate the practitioners' view point using survey strategy (See for example Ahmed, 2008; Ajija, Annisa, \& Hudaifah, 2012; Ascarya, 2010; Farooq \& Ahmed, 2013; Hanif \& Iqbal, 2010; Khalil et al., 2002); however these studies have the following limitations:

First, according to Yin (2003), "the survey designer, constantly struggles to limit the number of variables to be analyzed (and hence the number of questions that can be asked) to fall safely within the number of respondents that can be surveyed" ( $\mathrm{p}$. 13). The same problem prevails in the mentioned studies. Table 1 indicates that the extant literature highlights a large set of factors restraining the application of partnership contracts. However, these studies investigate a limited number of factors. Table 2 reports the number of constraints being investigated in the mentioned survey based studies.

Table 2: Number of constraints investigated in the survey based studies

\begin{tabular}{|c|c|}
\hline Studies & No. of constraints being investigated $^{*}$ \\
\hline Khalil et al. (2002) & 9 \\
\hline Ahmed (2008) & 4 \\
\hline Ascarya (2010) & 14 \\
\hline Hanif and Iqbal (2010) & 7 \\
\hline Ajija et al. (2012) & 10 \\
\hline Farooq and Ahmed (2013) & 11 \\
\hline
\end{tabular}

* The overlapping factors have been either eliminated or combined

Second, survey is not a suitable strategy if researcher wants to investigate, in depth, a contemporary phenomenon within its real life context because it has got an extremely limited capability to examine the context (Yin, 2003).

To extend our understanding of constraints in the application of partnership contracts beyond the prevailing explanations offered in the extant literature, future 
studies should more rigorously investigate the practitioners view point. Future studies should use methods other than survey including case study and grounded theory methodology since these methods are more flexible and enable researchers to explain the problem within its real life context. In a nut shell, need is felt for strong theory-building studies which could present deep insights about the problem at hand.

\section{Conclusion}

Partnership is the essence of Islamic banking and finance and represents the true spirit of an Islamic banking system. However, in practice Islamic banks tend to avoid partnership while investing. They rely heavily on the Shariah compliant non-partnership contracts for investing the funds. The strong and consistent tendency of Islamic banks to rely on non-partnership contracts has provided grounds for raising serious questions on the legitimacy of Islamic banks and their ability to meet the specific objectives of Islamic banking and the broader goals of the Shariah.

Islamic banks rely on non-partnership contracts for investment purposes because the partnership contracts have serious practical problems. Many researchers have provided different explanations for marginal utilization of partnership contracts by Islamic banks for investment purposes. Review of the extant literature indicates that asymmetric information, adverse selection, moral hazards, and agency problems in partnership contracts are the dominant constraints.

An important concentration apparent within the extant literature is the overwhelming attention given to academia's view point for explaining the tendency of Islamic banks to avoid partnership contracts; whereas the practitioners' viewpoint remain relatively unexplored. Therefore, future studies should investigate the practitioners view point more rigorously. In short, the problem of marginalization of partnership by Islamic banks needs creative reframing into a new theoretical vision that could provide deep insight about the problem. This will help in identification and better understanding of the factors that hinder the implementation of partnership contracts. Moreover, it would facilitate Islamic financial institutions, government, and regulatory authorities in policy implications to make the partnership contracts an attractive option. In short, these studies would act as a step towards economic growth and stability by playing major role in the promotion of partnership paradigm and helping Islamic banking in achieving its basic philosophy of being Islamic.

\section{References}

Abdouli, A. H. (1991). Access to finance and collaterals: Islamic versus western banking. Journal of King Abdulaziz University: Islamic Economics, 3(1), 55-62. 
Abou-Gabal, N., Khwaja, A. I., \& Klinger, B. (2011). Islamic finance and entrepreneurship: challenges and opportunities ahead. Entrepreneurial Finance Lab Research Initiative (EFLRI) Islamic Finance Whitepaper.

Adnan, M. A., \& Muhamad. (2008). Agency problems in mudarabah financing: The case of Sharia (Rural) banks, Indonesia. In M. Obaidullah \& H. S. H. A. Latiff (Eds.), Islamic finance for micro and medium enterprises (pp. 107-130): Islamic Research \& Training Institute, Islamic Development Bank.

Aggarwal, R. K., \& Yousef, T. (2000). Islamic banks and investment financing. Journal of Money, Credit and Banking, 32(1), 93-120.

Ahmad, K. (2000). Islamic Finance and Banking: The challenge and prospects. Review of Islamic Economics, $9,57-82$.

Ahmad, M. (1947). Economics of Islam: A comparative study. Lahore, Pakistan: Muhammad Ashraf.

Ahmed, G. A. (2008). Islamic micro-finance practice with a particular reference to financing entrepreneurs through equity participation contracts in Sudanese banks. In M. Obaidullah \& H. S. H. A. Latiff (Eds.), Islamic finance for micro and medium enterprises (pp. 75-105): Islamic Research \& Training Institute, Islamic Development Bank.

Ahmed, H. (2002). Incentive-compatible profit-sharing contracts: A theoretical treatment. In M. Iqbal \& D. T. Llewellyn (Eds.), Islamic Banking and Finance: New perspectives on profit-sharing and risk (pp. 40-54). Cheltenham, UK. Northampton, MA, USA: Edward Elgar.

Ajija, S. R., Annisa, E., \& Hudaifah, A. (2012). How do Islamic banks optimize profit and loss sharing arrangements? Paper presented at the Fourth Research Forum inIslamic Banking Bank Indonesia.

Akacem, M., \& Gilliam, L. (2002). Principles of Islamic banking: Debt versus equity financing. Middle East Policy, 9(1).

Al-Suwailem, S. (1998). Venture capital: A potential model of musharakah. Journal of King Abdulaziz University: Islamic Economics, 10, 3-20.

Algaoud, L. M., \& Lewis, M. K. (2007). Islamic critique of conventional financing. In M. K. Hassan \& M. K. Lewis (Eds.), Handbook of Islamic Banking: Edward Elgar Publishing Limited.

Amrani, F. (2012, June 28-29). Financing cost and risk sharing in Islamic finance: A new endogenous approach. Paper presented at the 29th International Symposium on Money, Banking and Finance, NantesFrance.

Archer, S., Karim, R. A. A., \& Al-Deehani, T. (1998). Financial contracting, governance structures and the accounting regulation of Islamic banks: An analysis in terms of agency theory and transaction cost economics. Journal of Management and Governance, 2, 149-170.

Ariff, M. (1988). Islamic banking. Asian-Pacijlc Economic Literature, 2(2), 48-64.

Ascarya. (2010). The lack of profit-and-loss sharing financing in Indonesia's islamic banks revisited. Review of Indonesian Economic and Business Studies, 1(1), 57-80. 
Ascarya, \& Yumanita, D. (2006). The lack of profit and lost sharing financing in Indonesian Islamic banks: Problems and alternative solutions. Paper presented at the INCEIF Islamic Banking and Finance Educational Colloquium, KL Convention Center, Kuala Lumpur, Malaysia.

Bacha, O. I. (1995). Conventional versus mudarabah financing: An agency cost perspective. Journal of Islamic Economics, 4(1\&2), 33-49.

Bacha, O. I. (1997). Adapting mudarabah financing to contemporary realities: A proposed financing structure. The Journal of Accounting, Commerce E Finance, 1(1).

Bashir, A. H. M. (1996). Investment under profit-sharing contracts: The adverse selection case. Managerial Finance, 22(5/6), 48-58.

Berger, A. N., \& Udell, G. F. (1998). The economics of small business finance: The roles of private equity and debt markets in the financial growth cycle. Journal of Banking $\mathcal{E}$ Finance, 22(6), 613-673.

Boumediene, A. (2011). Is credit risk really higher in Islamic banks? The Journal of Credit Risk, 7(3), 97-129.

Chapra, M. U. (2002). Alternative visions of international monetary reform. In M. Iqbal \& D. T. Llewellyn (Eds.), Islamic Banking and Finance: New perspectives on profit-sharing and risk (pp. 219-240). Cheltenham, UK. Northampton, MA, USA: Edward Elgar.

Chong, B. S., \& Liu, M.-H. (2009). Islamic banking: Interest-free or interest-based? Pacific-Basin Finance Journal, 17, $125-144$.

Dar, H. A., Harvey, D. I., \& Presley, J. R. (1999). Size, profitability, and agency in profit and loss sharing in Islamic banking and finance. Paper presented at the Second Harvard University Forum on Islamic Finance: Islamic Finance into the 21st Century, Cambridge, Massachusetts.

Dar, H. A., \& Presley, J. R. (2000). Lack of proit loss sharing in islamic banking: Management and control imbalances. International Journal of Islamic Financial Services, 2(2), 3-18.

Dees, J. G. (1992). Principals, agents, and ethics. In N. E. Bowie \& R. E. Freeman (Eds.), Ethics and agency theory : an introduction. New York: Oxford University Press.

Dusuki, A. W. (2007). The ideal of Islamic banking: A survey of stakeholders' perceptions. Review of Islamic Economics, 11(Special Issue), 29-52.

Ebrahim, M. S., \& Safadi, A. (1995). Behavioral norms in the islamic doctrine of economics: A comment Journal of Economic Behavior and Organization, 27, 151-157.

El-Din, S. I. T. (2008). Income ratio, risk-sharing, and the optimality of Mudarabah. The Journal of King Abdulaziz University, Islamic Economics, 21(2), 37-59

El-Gamal, M. A. (2005). Islamic bank corporate governance and regulation: A call for mutualization. Rice University.

El-Komi, M., \& Croson, R. (2013). Experiments in islamic microinance. Journal of Economic Behavior $\mathcal{E}$ Organization, 95, 252-269. 
ElGindi, T., Said, M., \& Salevurakis, J. W. (2009). Islamic alternatives to purely capitalist modes of finance: A study of Malaysian banks from 1999 to 2006. Review of Radical Political Economics, 41 (4), 516-538.

Farooq, M., \& Ahmed, M. M. M. (2013). Musharakah financing: Experience of Pakistani banks. World Applied Sciences Journal, 21(2), 181-189.

Farooq, M. O. (2007). Partnership, equity-financing and Islamic finance: Whither profit-loss sharing? Review of Islamic Economics, 11(Special Issue), 22.

Gafoor, A. A. L. M. (1995). Interest-free commercial banking. Netherlands: Apptec Publications.

Hanif, M., \& Iqbal, A. M. (2010). Islamic financing and business framework: A survey. European Journal of Social Sciences, 15(4), 475-489.

Hasan, Z. (2002). Mudaraba as a mode of finance in islamic banking: Theory, practice and problems. The Middle East business and economic review, 14(2), 41-53.

Hearn, B., Piesse, J., \& Strange, R. (2012). Islamic finance and market segmentation: Implications for the cost of capital. International Business Review, 21, 102-113.

Hicks, S. J. (1982). Limited liability: The pros and cons. In T. Orhnial (Eds.), Limited liability and the corporation. London, UK: Croom Helm.

I.C.M.T Force. (2004). Islamic capital market fact finding report. Madrid: Islamic Capital Market Task Force, The International Organization Of Securities Commissions.

Iqbal, M., \& Molyneux, P. (2005). Thirty years of Islamic banking: History, performance and prospects. New York: Palgrave Macmillan.

Iqbal, Z. (1997). Islamic Financial Systems. Finance E Development, June, 42-45.

Karim, A. A. (2002). Incentive-compatible constraints for Islamic banking: Some lessons from Bank Muamalat. In M. Iqbal \& D. T. Llewellyn (Eds.), Islamic Banking and Finance: New perspectives on profit-sharing and risk (pp. 95-108). Cheltenham, UK. Northampton, MA, USA: Edward Elgar.

Kayed, R. N. (2012). The entrepreneurial role of profit-and-loss sharing modes of finance: Theory and practice. International Journal of Islamic and Middle Eastern Finance and Management, 5(3), 203 - 228.

Khalil, A. F. A. A., Rickwood, C., \& Murinde, V. (2002). Evidence on agency-contractual problems in mudarabah financing operations by Islamic banks. In M. Iqbal \& D. T. Llewellyn (Eds.), Islamic Banking and Finance: New perspectives on profit-sharing and risk (pp. 57-92). Cheltenham, UK. Northampton, MA, USA: Edward Elgar.

Khan, F. (2010). How 'Islamic' is islamic banking? Journal of Economic Behavior $\mathcal{E}$ Organization, 76, 805-820.

Khan, T. (1995). Demand for and supply of PLS and mark-up funds of Islamic banks: Some alternative explanations. Islamic Economic Studies, 3(1).

Khan, T., \& Ahmed, H. (2001). Risk management: An analysis of issues in Islamic financial industry. Jeddah: Islamic Research and Training Institute-Islamic Development Bank. 
Khan, W. M. (1989). Towards an interest-free Islamic economic system. Journal of King Abdulaziz University: Islamic Economics, 1, 3-38.

Kuran, T. (1995). Further reflections on the behavioral norms of Islamic economics. Journal of Economic Behavior and Organization, 27, 159-163

Lewis, M. K. (2008). In what ways does Islamic banking differ from conventional finance? Journal of Islamic Economics, Banking and Finance, 4(3).

Mills, P. S., \& Presley, J. R. (1999). Islamic finance: Theory and practice USA: Palgrave Macmillan.

Mirakhor, A., \& Zaidi, I. (2007). Proit-and-loss sharing contracts in Islamic finance. In K. Hassan \& M. Lewis (Eds.), Handbook of Islamic Banking (pp. 49-63): Edward Elgar Publishing.

Mishkin, F. S., \& Eakins, S. G. (2011). Financial markets and institutions (7 ed.). Prentice Hall.

Naughton, S., \& Naughton, T. (2000). Religion, ethics and stock trading: The case of an Islamic equities market. Journal of Business Ethics, 23(2), 145-159.

Pryor, F. L. (2007). The economic impact of islam on developing countries. World Development, 35(11), 1815-1835.

Qureshi, A. I. (1946). Islam and the theory of interest (1st ed.). Lahore, Pakistan: Muhammad Ashraf Publishers.

Rethel, L. (2011). Whose legitimacy? Islamic finance and the global financial order. Review of International Political Economy, 18(1), 75-98.

Sadique, M. A. (2010). Islamic banks' dilemma between ideals and practice: Debt or equity Global Journal of Management and Business Research, 10(2).

Sadique, M. A. (2012). Capital and profit sharing in Islamic equity financing : Issues and prospects. Kuala Lumpur: The Other Press.

Samad, A., Gardner, N. D., \& Cook, B. J. (2005). Islamic banking and finance in theory and practice: The experience of Malaysia and Bahrain. The American Journal of Islamic Social Sciences, 22(2), 69-86.

Sarker, M. A. A. (1999). Islamic business contracts, agency problem and the theory of the Islamic firm. International Journal of Islamic Financial Services, 1(2).

Sen, A. (1987). On ethics and economics. Oxford, New York: Basil Blackwell.

Shinsuke, N. (2012). Critical overview of the history of islamic economics: Formation, transformation, and new horizons. Asian and African Area Studies, 11(2), 114-136.

Siddiqi, M. N. (1981). Muslim economic thinking. Leicester: Islamic Foundation.

Siddiqi, M. N. (1983a). Banking without interest. Leicester, UK: Islamic Foundation (originally published in Urdu).

Siddiqi, M. N. (1983b). Issues in Islamic banking. Leicester, U.K.: The Islamic Foundation. 
Siddiqi, M. N. (1985). Partnership and profit-sharing in Islamic law. Leicester, U.K.: The Islamic Foundation.

Siddiqi, M. N. (1991). Some economic aspects of mudarabah: Review of Islamic economics. Journal of the International Association for Islamic Economics, 1(2), 21-34.

Siddiqi, M. N. (2006). Islamic banking and finance in theory and practice: A survey of state of the art Islamic Economic Studies, 13(2).

Sole, J. (2007). Introducing Islamic Banks into Conventional Banking Systems. IMF Working Papers. Monetary and Capital Markets Department. International Monetary Fund.

Sumarti, N., Fitriyani, V., \& Damayanti, M. (2014). A mathematical model of the profit-loss sharing (PLS) scheme Procedia - Social and Behavioral Sciences, 115, 131 - 137.

Sundararajan, V., \& Errico, L. (2002). Islamic financial institutions and products in the global financial system: Key issues in risk management and challenges ahead. International Monetary Fund Working Paper Working Paper, WP/02/192.

Usmani, M. T. (2002). An introduction to Islamic finance. The Hague: Kluwer Law International.

Usmani, M. T. (2007). An introduction to islamic finance. Karachi, Pakistan: Maktaba Ma'ariful Qur'an.

Uzair, M. (1978). Interest-Free Banking. Karachi, Pakistan: Royal Books.

Vahed, G., \& Vawda, S. (2008). The viability of islamic banking and finance in a capitalist economy: A South African case study. Journal of Muslim Minority Affairs, 28(3), 453-472.

Vogel, F. E., \& Hayes, S. L. (1998). Islamic law and finance: Religion, risk and return. The Hague: Kluwer Law International.

Wilson, R. (2002). The interface between islamic and conventional banking. In M. Iqbal \& D. T. Llewellyn (Eds.), Islamic Banking and Finance: New perspectives on profit-sharing and risk (pp. 196-218). Cheltenham, UK. Northampton, MA, USA: Edward Elgar.

Wolozin, H. (2002). The individual in economic analysis: Toward psychology of economic behavior. Journal of Socio-Economics, 31, 45-57.

Yin, R. K. (2003). Case study research: Designs and methods (3rd ed.). Thousand Oaks, CA: Sage Publications.

Yousef, T. M. (2004). The murabaha syndrome in islamic finance: Laws, institutions and politics. In C. Henry \& R. Wilson (Eds.), The politics of Islamic finance. Edinburgh: Edinburgh University Press.

Yousefi, M., McCormick, K., \& Abizadeh, S. (1995). Islamic banking and Friedman's rule. Review of Social Economy, 53(1), 65-87.

Zaher, T. S., \& Hassan, M. K. (2001). A comparative literature survey of Islamic finance and banking. Financial Markets, Institutions $\mathcal{E}$ Instruments, 10(4), 155-199. 
